\title{
ADVISORY OPINION AND PRELIMINARY RULING PROCEDURE - A COMPARATIVE AND CONTEXTUAL NOTE
}

Summary: The apropos of this article is Additional Protocol No. 16 complementing to the European Convention on Protection of Human Rights and Fundamental Freedoms that recently came into force. This paper presents the main common and differing elements of two non-contentious procedures before supranational courts. The advisory opinion procedure of European Court of Human Rights (ECtHR) and the preliminary ruling procedure marked by unprecedented success before the Court of Justice of the European Union, -as at least prima facie-similar types of proceedings. The paper also analyses cross-cutting issues arising from the application of both procedures in the same case arising before designated national court or tribunal. Although the purpose of the advisory opinion is to achieve and maintain efficiency bearing in mind that the ECtHR is victim of its own success the paper outlines some of serious doubts and assumptions whether in current format and in foreseeable future this purpose will be achieved. Furthermore, the paper also takes a closer look at the procedural aspects of the first advisory opinion delivered by ECtHR given its importance as we can draw at least some conclusions on the functioning of this type of procedure. Lastly, the paper-in comparative spirit-also refers to the relationship of the ECHR and the European Union Law as the two main trustees within the European multilevel system of rights protection.

Keywords: $\quad$ Additional Protocol No. 16, advisory opinion, preliminary ruling procedure, relationship of the ECHR and the European Union Law 


\section{INTRODUCTORY REMARKS}

The European Court of Human Rights (hereinafter ECtHR) and Court of Justice of the European Union (hereinafter CJEU) both supranational courts -although with distinctive missions- serve as external control mechanism, the first one to Council of Europe (CoE) Member States and the second one to the Member States of European Union, whereas members states of the latter are in the same time member states of the CoE.

Back in 1976, Advocate General Warner in his opinion in the case Vivien Prais v. Council of the European Communities concluded "I regret the absence from that Convention of any power for this Court, or for national courts, to refer to the European Court of Human Rights for preliminary ruling questions of interpretation of the Convention that arise in cases before them." 1

Although it took more than 40 years, such procedure came into force recently via Additional Protocol No. $16^{2}$ (hereinafter: Protocol No. 16) complementing to the European Convention on Protection of Human Rights and Fundamental Freedoms (hereinafter ECHR, the Convention) - albeit only regarding national courts, and just some of them. ${ }^{3}$ As regards the EU legal order, there is a long lasting institutionalized non-contentious procedure, the preliminary ruling procedure, which is certainly a well-known cornerstone of EU law. Given the fact that both procedures have - at least prima facie - common features, both are regarded as means of communication, ${ }^{4}$ it is worth taking a closer look and also placing them in a broader context within the unique European human rights system.

With regard for the written signs of connection between the courts, it is well-known that TEU ${ }^{5}$ Article 6 governs three area of fundamental rights protection, vesting with binding power the Charter of Fundamental Rights, (Article 6 (1)), under Article 6 (2)) it gives the legal ground for EU accession to the ECHR which is still on hold, and under Article 6 (3)) it rules that fundamental rights exist is parallel way, ${ }^{6}$ as guaranteed by ECHR, ${ }^{7}$ and as they result from the constitutional traditions common to the Member States, and they constitute general principles of Union law.

1 Vivien Prais v Council of the European Communities, Opinion of Mr Advocate General Warner 1976. C 130-75., ECLI: ECLI:EU:C:1976:124.

2 Protocol No. 16 to the Convention on the Protection of Human Rights and Fundamental Freedoms. Council of Europe Treaty Series No. 214 (CETS No.214).

3 The issue of national courts entitled to initiate advisory opinion will be outlined in the upcoming chapters.

4 Karoliny, E.; Komanovics, A.; Mohay, Á.; Pánovics, A.; Szalayné Sándor, E., Az Európai Unió joga, Dialóg Campus, Budapest-Pécs, 2015, p. 168.

5 Treaty on European Union OJ 2012 C 326/1.

6 Mohay, Á., A nemzetközi jog érvényesülése az uniós jogban. PTE ÁJK Európa Központ / Publikon, Pécs, 2019, p. 56.

7 The most recent example of direct application of ECHR is the Dorobantu judgement delivered by CJEU, which -inter alia- stated that, the personal space available to each detainee, the executing judicial authority must, in the absence, currently, of minimum standards in that respect under EU law, take account of the minimum requirements under Article 3 of the ECHR, as interpreted by the European Court of Human Rights. Although, in calculating that available space, the area occupied by sanitary facilities should not be taken into account, the calculation should include space occupied by furniture. Detainees must, however, still have the possibility of moving around normally within the cell. C128/18, ECLI:EU:C:2019:857.

See further: Mohay, Á., Plot twist? Case C-128/18 Dorobantu: detention conditions and the applicability of the ECHR in the EU legal order. http://eulawanalysis.blogspot.com/search?q=plot+twist. Accessed 08 April 2020. 
The frequently heard statement according to which the ECtHR is the victim of its own success is quite undisputed. ${ }^{8}$ Not going into the reasons ${ }^{9}$ of the adoption of the protocol, I will just briefly state that the introduction of advisory opinion procedure was seen as one of the measures to achieve and maintain efficiency. ${ }^{10}$ As per the advisory opinion procedure - if we are optimistic - it may be expected that upon the motion of national courts the ECtHR decides on the referred question and as a consequence the individual gets adequate legal remedy without lodging complaint with the ECtHR.

When embarking on a journey to discover whether this prediction will actually happen in practice, the paper will use the following methodology and structure. In order to support the conclusion and context of the paper, the research is supported by both qualitative and quantitative methods. This means primarily analyzing and drawing conclusion from the case law of the ECtHR and CJEU, including also comparison of judgments and decisions along with their reasoning with earlier documents. By citing publications from the academia, as point of reference, both explaining what a judgment or decision does not explicitly say and commenting on the choices made by the forums. The paper is divided into five thematic chapters dedicated to different stages and contexts, such as introduction, the analysis of the two non-contentious procedures in general, cross-cutting issues, examination of the first advisory opinion and lastly putting things in wider context by giving some food for thought regarding European regional human rights system.

\section{THE PRELIMINARY RULING PROCEDURE AND THE ADVISORY OPINION COMPARED}

\section{SOME GENERAL REMARKS ON THE ADVISORY OPINION - A PROCEDURE WITH TOO MANY “IFS”}

This part of the paper is dedicated to comparing the elements of two procedures and drawing preliminary conclusion whether the procedures can be regarded either similar in essence or not. Before that, some general remarks. First of all, it is important to outline that the ad-

8 See e.g. Helfer, R. L., Redesigning the European Court of Human Rights: Embeddedness as a Deep Structural Principle of the European Human Rights Regime The European Journal of International Law 2008, Vol. 19 no. 1, p.125.

9 High Level Conference on the Future of the European Court of Human Rights organised in 2011 in Izmir explicitly enumerated the advisory opinion as one of the desired follow up plan measures in its declaration aimed at more effective Convention system. See the whole declaration: https://www.echr.coe .int/Documents/2011-Izmir-FinalDeclaration-ENG.pdf. Accessed 08 April 2020.

Afterwards in 2012 the Brighton Declaration -inter alia- initiated concrete measures, such as inviting the Committee of Ministers to draft the text of an optional protocol to the Convention with this effect by the end of 2013; and further invites the Committee of Ministers thereafter to decide whether to adopt it; See the whole declaration: https://www.echr.coe.int/Documents/2012Brighton-FinalDeclaration-ENG.pdf. Accessed 8 April 2020.

10 In order to achieve and maintain the efficiency of ECHR regime, to date more instruments were introduced such as the adoption of Protocol No. 14 which introduced -inter alia-the additional criteria shortly referred to as significant disadvantage. Furthermore, the planned introduction of 4 months deadline as introduced by the Protocol No. 15. is also one such measure. As concluded back in 2006 in the report of the group of wise persons the Council of Europe by looking for more effective human rights protecting mechanisms proposed -inter alia- the institutionalization of the relationship between the Court and national courts in the form of non-binding advisory opinion. See the report of the Group of Wise Persons to the Committee of Ministers https://search.coe.int/cm/Pages/result-details.aspx?ObjectID=09000016805d7893. Accessed 13 April 2020. 
visory opinion is relatively similar to the judicial procedure before the ECtHR. ${ }^{11}$ Referring to efficiency and caseload management, if we presume that the ECtHR clarifies ECHR principles in the form of advisory opinions, if the court "would do so correctly and conscientiously that would result in a lower number of cases to arrive at the Court, since this would mean that most cases would be satisfactorily solved at the national level."12 However, analyzing the Court's caselaw and statistics it is evident that the vast number of requests do not relate to interpretations of principle, but to structured systemic issues such as the violation of the right to a fair trial, the prohibition of inhumane and degrading treatment, etc. ${ }^{13}$ In my view, it is highly questionable whether in practice the reduction of the ECtHR's caseload - which will probably happen to some extent and in the long run - will be of significant volume.

Secondly, the overall significance of the advisory opinion is undermined by the low number of ratifications, so far only $15 .{ }^{14}$ On that note, the true willingness and preparedness of national courts to initiate dialogue in the form of advisory opinions is in my view not obvious. However, even if the advisory opinion is accepted and delivered by the Court, it is still questionable whether the national court will 'transpose' the Courts' decision.

The aim of Protocol No. 16 is to inform the national courts and give guidance on certain ECHR principles thus reducing the ECtHR's caselaw as well as strengthening the Convention system. Although Protocol No. 16 does not define what is to be understood under above-mentioned principle, the Article 43 (2) ECHR ${ }^{15}$ might give some guidance. Accordingly this concept is basically twofold; either a serious question affecting the interpretation or application of the Convention or the Protocols, or a serious issue of general importance. ${ }^{16}$ By delivering advisory opinion the ECtHR expects that the dispute will be solved on national level and that the individual in concrete case will not tend to file application for judicial proceedings at the ECtHR. The assumption is that thus the judicial workload will be reduced what then constitutes more effective Convention system. However, in my view it is quite doubtful whether the guidance offered in advisory opinions will at the end result in actual caseload reduction.

These two remarks illustrate that the success of the advisory opinion system lies on many assumptions, and those are just some of the "ifs" surrounding this procedure.

11 Even though the advisory opinion procedure was already in force even before the Protocol No. 16 entered into force, its rationae personae and rationae materie applicability was/is different. Namely, under that procedure, governed by Article $47 \mathrm{ECHR}$ is meant that " 1 . The Court may, at the request of the Committee of Ministers, give advisory opinions on legal questions concerning the interpretation of the Convention and the Protocols thereto. 2. Such opinions shall not deal with any question relating to the content or scope of the rights or freedoms defined in Section I of the Convention and the Protocols thereto, or with any other question which the Court or the Committee of Ministers might have to consider in consequence of any such proceedings as could be instituted in accordance with the Convention. 3. Decisions of the Committee of Ministers to request an advisory opinion of the Court shall require a majority vote of the representatives entitled to sit on the committee." See more: https://www.echr.coe. int/Documents/Convention-ENG.pdf. Accessed 13 April 2020.

Gerards J., Advisory Opinions, preliminary rulings and the new protocol No.16 to the European Convention on Human Rights: A comparative and critical Appraisal, Maastricht Journal of European and Comparative law, 2014, Issue 4. p. 639. See e.g. the statistics for 2019: https://www.echr.coe.int/Documents/Stats-violation-2019-ENG.pdf. Accessed 13 April 2020. and Fundamental Freedoms Status as of 02 July 2020, https://www.coe.int/en/web/ conventions/full-list/-/conventions/ treaty/214/signatures?p-auth=AN3GPheM. Accessed 2 July 2020. affecting the interpretation or application of the Convention or the Protocols thereto, or a serious issue of general importance." 


\section{COMMON ELEMENTS}

\section{THE FORM OF LEGAL REGULATIONS IN PLACE}

As already outlined, the possibility to seek advisory opinion comes in the form of an additional protocol. This form has several characteristics, such as that this is only an option for the Contracting Parties, not an obligation. Furthermore, the parties are entitled - in a limited way, but still - to make reservations ${ }^{17}$ which further limits its power. Therefore, the Contracting States can decide whether they want to 'join the club' of Protocol No. 16 and if they do so they have certain margin of appreciation to have reservations. As already mentioned, so far only 15 states ratified the protocol, out of which 9 are EU Members States.

As for the preliminary ruling procedure, the regulation is enshrined in primary EU law, Article 276 TFEU. As a consequence, the EU Members States do not enjoy any margin of appreciation whether they agree with this procedure once they accede to the EU, as in the moment of accession to the EU all the Members accepted the provisions of EU law, including those governing preliminary ruling procedures. This procedure is one of the most frequently applied before the CJEU in which numerous fundamental rights based and oriented interpretations from Stauder ${ }^{18}$ to Dorobantu ${ }^{19}$ have evolved.

One could say that Protocol No. 16 is a sort of a la carte option while the preliminary ruling procedure is part of the of table d'hote offer.

\section{THE MAIN GOAL OF THE PROCEDURES}

Although the aim of the preliminary ruling procedure is not regulated by the TFEU expressly, from the provisions of Article 267 it is evident that that the uniform interpretation of primary law and the uniform interpretation and judicial review of secondary law are the ultimate aims. Of course, the preliminary ruling procedure does not only concern the interpretation and validity of fundamental rights, conversely it would be better to say the human rights-based approach is only ancillary. This goes in line with the core of the European integration process being primarily economic. Needless to say, with the development of integration its content has also been deepened and broadened which is also reflected in the strengthening of its human rights-based approach. Given the fact that in certain cases the national courts have not only the possibility but an obligation to request preliminary rulings, it further enhanced the unique application of the law.

The aim of the advisory opinion is enshrined in the preamble of Protocol No. 16 referring to the strengthening of dialogue between highest national courts and reinforcing thus the application of Convention. ${ }^{20}$ This was also reaffirmed in the first advisory opinion delivered by

\footnotetext{
17 See more about reservations: Shaw, M. N., International Law, sixth edition, Cambridge University Press 2008 pp. 913-925.

18 C-29-69, ECLI:EU:C:1969:57.

19 C128/18, ECLI:EU:C:2019:857.

20 Protocol No. 16 to the Convention for the Protection of Human Rights and Fundamental Freedoms CETS No. 214 https://www. coe.int/en/web/conventions/full-list/-/conventions/rms/0900001680084832. Accessed 14 April, 2020.
} 
the Grand Chamber. ${ }^{21}$ Contrary to the preliminary ruling procedure, the uniform application of the law cannot be guaranteed in this case. In line with Article 53 of the Convention, the ECtHR serves rather as a point of reference for minimum standards of national decisions. In case of both procedures, i.e. advisory opinion and preliminary ruling procedure, in general no abstract judicial review takes place, except for some cases of secondary law review under the preliminary ruling procedure.

In practice, this would mean that both court's decisions will be incorporated into the national decision without the individual directly standing before a supranational court.

In the case of the preliminary ruling procedure, the situation is quite straightforward. In the case of advisory opinions, the construction of the process raises several questions. First of all, given the fact that the advisory opinion is not binding, the requesting court might disregard the interpretation given by the ECtHR. In such cases we cannot state that the advisory opinion effectively replaces the judicial procedure of ECtHR. The opposite happened however in the first advisory opinion that concerned the interpretation of a question regarding which the ECtHR previously already delivered a judgement in the case of Mennesson v. France. ${ }^{22}$

In the case of both non-contentious procedures there is an opportunity for direct interaction between national courts and the European court, ${ }^{23}$ however the dialogue takes place on different levels. In both cases the initial proceedings are suspended, the suspension is regulated by national procedural laws. This principle is also enshrined in the guidelines issued by the ECtHR stating that it is up to the requesting court to decide whether the domestic proceedings are to be suspended pending the delivery of the Court's advisory opinion. ${ }^{24}$

\section{THIRD PARTIES}

Both procedures foresee the possibility for persons directly not involved in the proceedings to present their observations.

The regulations with regard to the third parties look similar in both cases. As for the preliminary ruling, the CJEU's Rules of Procedure give more guidance ${ }^{25}$ and we can say that the CJEU criteria in the subject matter are more sophisticated. ${ }^{26}$ In comparison, the wording of Protocol No. 16 is quite reticent. Article 3 points out the possibility for the Council of Europe Commissioner for Human Rights and the High Contracting Party to which the requesting court or tribunal pertains shall have the right to submit written comments and take part in any hearing. Additionally, the President of the Court may, in the interest of the proper admin-

21 Advisory opinion concerning the recognition in domestic law of a legal parent-child relationship between a child born through a gestational surrogacy arrangement abroad and the intended mother, Request no. P16-2018-001Para 25. Accessed 14 April 2020.

22 Mennesson v. France, Application No.: 65192/11, ECLI:CE:ECHR:2014:0626JUD006519211.

23 Gerards, J., Ibid. p. 641.

24 Guidelines on the implementation of the advisory-opinion procedure introduced by Protocol No. 16 to the Convention (as approved by the Plenary Court on 18 September 2017) https://www.echr. coe.int/ Documents/Guidelines-P16-ENG.pdf. Para 8. Accessed 14 April 2020.

25 Rules of Procedure of the Court of Justice OJ L 265/1. Accessed 14 April 2020. 
istration of justice, invite any other High Contracting Party or person also to submit written comments or take part in any hearing -if it occurs at all.

\section{FORM(AT) OF THE REQUEST AND THE QUESTION OF PRECEDENT}

The format of the request looks similar before both courts, the request(s) should be clear and concise consisting of the relevant legal and factual background of the case. ${ }^{27}$ Besides the already cited Rules of Procedure, the CJEU has issued also Recommendations to national courts and tribunals, in relation to the initiation of preliminary ruling proceedings ${ }^{28}$ further elaborating on the given criteria (this latter document is of course legally non-binding).

In this context we also have to address the issue of quasi-precedents. That is to stay the orienting, directing nature of the courts previous judgements and decisions. Some authors, including Gerards claim that the ECtHR judgements and decisions should be considered res interpretata meaning that the interpretation given by ECtHR form part of its caselaw. If we agree that the legal effect of advisory opinions is similar to judgments this means that they too will have res interpretata. ${ }^{29}$ The question arises how the res interpretata can fit into a non-binding advisory opinion? In case of judicial proceedings, judgments have binding force and have to be executed under the Convention provisions, ${ }^{30}$ but will or could the non-binding advisory opinion mitigate or better to say soften the power of res interpretata?

It is suggested that in formal manner the answer is negative, because the provisions of Article 46 ECHR apply only to judgements not advisory opinions. However, it will be interesting to see if an advisory opinion delivered by ECtHR will be put aside by the requesting national court. In informal manner that would not only decrease the relevance of the res interpretata but the whole advisory opinion-system set up with the aim for more effective convention system. What a contradiction!

On a side note of addressing precedent, one cannot disregard the question of coherency and consistency of decisions and judgments delivered by the ECtHR as not all of them - if we take as example the cases of Bankovic ${ }^{31}$ and Al-Skeini ${ }^{32}$ - are, or at least appear to be coherent. For reconciliation of contradicting interpretations - since the Tyrer ${ }^{33}$ case - the concept of living instrument should be applied.

The importance of a quasi-precedent system is enhanced by the fact that so far there is no external human rights control mechanism in the EU legal order (pending the EU's accession to the ECHR). Therefore, the lack of such mechanism puts additional emphasis on the judge made law in the field of fundamental rights protection too. Such precedent-like cases show guidance regarding the external borders of fundamental rights protection.

Protocol No. 16 Art. 1 (3) and Rules of Procedure of the Court of Justice Art. 94.

Recommendations to national courts and tribunals, in relation to the initiation of preliminary ruling proceedings 2016/C 439/01. Accessed 14 April 2020.

Gerards, J., Ibid. p. 635.

See ECHR Article 46.

Banković and Others v. Belgium and Others 52207/99 ECLI:CE:ECHR:2001:1212DEC005220799.

Al-Skeini and Others v. the United Kingdom 55721/07 ECLI:CE:ECHR:2011:0707JUD005572107.

Tyrer v. United Kingdom 5856/72 ECLI:CE:ECHR:1978:0425JUD000585672. 


\section{DIFFERENCES}

Let us take a closer look now at the existing differences between the two procedures. As for the legal basis of the preliminary ruling procedure, Article 267 TFEU provides for, the interpretation of the Treaties and the review of the validity and the interpretation of acts of the institutions, bodies, offices or agencies of the Union. On the contrary, Protocol No. 16 legal basis, defined in Article 1 relates to the questions of principle relating to the interpretation or application of the rights and freedoms defined in the ECHR or the protocols thereto. On this quite vague wording I already elaborated under the general remarks of this chapter; it is much less straightforward than Article 267 TFEU. The question of principle approach is confirmed also in the first delivered advisory opinion, however no closer hint is given what may amount to it. ${ }^{34}$

With regard to the duty to submit a motion, there is no duty at all regarding advisory opinion, it is a mere possibility for the designated national courts. Unlike in EU legal order, where the criteria are again more sophisticated, the duty to refer a question to CJEU is not only a right but in certain cases an obligation of the national court ${ }^{35}$ without any margin of appreciation. This can happen if the primary proceedings are taking place before such national court against whose decision there is no legal remedy.

Agreeing with Gerards, "the existence of an obligation rather than a mere competence to refer preliminary questions to the CJEU in cases where new issues of interpretation have arisen has resulted in the frequent involvement of the CJEU in national cases and contributed to the major impact of its judgements and interpretations." ${ }^{36}$

With regard to the designated courts in charge of submitting requests for preliminary rulings or advisory opinions, the situation is again quite nuanced. In the case of advisory opinions, those entitled are the highest courts and tribunals of the States Parties. In practice a published list of these courts exists. ${ }^{37}$ Due to the differences in national judicial systems, this basically means that States enjoy considerable freedom to decide which high level courts to authorize with the competence to ask for an advisory opinion, they have the power to evaluate what level is to be considered as appropriate. The practice is quite differing, and it would be an interesting question to answer - after a certain period of time has elapsed - whether there is a strong correlation between the number of designated courts by the Member States and the number of requested advisory opinions.

As for the concept of 'court', again the CJEU has a much more sophisticated approach, meaning that the definition of a court is not necessarily the same in the national laws and before the CJEU in the context of the right to initiate preliminary ruling procedures. Usually it will be examined in concerto. ${ }^{38}$ Just another difference between the two non-contentious procedures.

34 Advisory opinion, Ibid. Article 25-26.

35 Blutman, L., Az Európai Unió joga a gyakorlatban, HVG ORAC Budapest, 2014 p. 122.

36 Gerards, J., Ibid. p. 642.

37 Reservations and Declarations for Treaty No.214 - Protocol No. 16 to the Convention for the Protection of Human Rights and Fundamental Freedoms Declarations in force as of today.

Status as of 11/04/2020 https://www.coe.int/en/web/conventions/full-list/-/conventions/treaty/214/declarations? p-auth=TDHtzNVl. Accessed 11 April 2020.

38 See e.g. the case Dorsch Consult where the CJEU back in 1997 elaborated on the meaning of national court or tribunal. Dorsch Consult Ingenieurgesellschaft mbH v Council of the European Union and Commission of the European Communities C54/96 ECLI:EU:C:1997:413. 
For the CJEU, its Rules of Procedure regulate the expedited and urgent preliminary ruling procedures, ${ }^{39}$ procedures which developed over time in the EU legal order. On the contrary, in the case of the ECtHR's advisory opinion we do not have such a historical and evolutive context against which we could measure its development. In my understanding, this difference stems from different goals which these non-contentious procedures aim to achieve.

Another differing aspect revolves around of the actual decision delivered by the respective supranational courts. Here we can distinguish several differing elements actually.

Firstly, the preliminary ruling procedure can be considered as a unique procedure, where the bench reaches unanimous decision although we are not aware in practice how many of judges actually were in favor of certain decision. The question of separate and dissenting opinion is far beyond the scope of this paper, it is frequently voiced thought that before the CJEU, such modus operandi would endanger the authority of the law and the court's interpretation might be affected. "Therefore, separate opinions are considered a threat to the unitary application of the law and the authority of the Court." ${ }^{40}$ Whereas Protocol No. 16 foresees the possibility of delivering separate opinions if the advisory opinion does not represent, in whole or in part, the unanimous opinion of the judges.

Secondly, speaking of the legal effect of the decisions, there is a further distinction. The judgements delivered in preliminary ruling procedures are binding. Although the TFEU expressis verbis states this, based on the functions of the procedure we still can draw that conclusion which is also reaffirmed by general practice. Although the decision is binding in the concrete case, because of the authentic interpretation of EU law and the aforementioned quasi-precedent system it is not only relevant for the concrete case but beyond that as well. ${ }^{41}$ Advisory opinions on the other hand are non-binding, the national court decides if it will apply it. According to guidelines issued by the Court the requesting court should submit a follow-up, ${ }^{42}$ this is still no legal obligation. Another "if".

What are the reasons for these crucial differences? I believe they stem from the differing relationships between the supranational courts and the member states.

In particular, the Strasbourg Court, in accordance with Article 53 of the Convention, aims at establishing a minimum level of human rights protection throughout all forty- seven Member States. The Convention does not aspire to harmonize the various systems of fundamental rights protection developed at national level, but rather at securing a common basis. ${ }^{43}$ "The raison d'être of the EU judiciary is not to ensure a minimum protection of fundamental rights in

39 Rules of Procedure of the Court of Justice Title III, Chapter 2 and Chapter 3.

40 Paulus, A., Opening of the Judicial Year Seminar Judgments and Separate Opinions: Complementarity and Tensions https://www.echr. coe.int/Documents/Speech-20190125-Paulus-JY-ENG.pdf. Accessed 20 February 2020.

41 See e.g. Mohay, Á., Az elôzetes döntéshozatali eljárás. In: Mohay, Á., Szalayné Sándor, E., (eds), Az Európai Unió joga: C/2. témakör: Az Európai Unió joga. Dialóg Campus, Budapest-Pécs 2015, pp.168-180.

42 Guidelines, Ibid. Article 12.

43 Spielmann, D., The Judicial Dialogue between the European Court of Justice and the European Court of Human Rights Or how to remain good neighbors after the Opinion 2/13 http://www.fp7-frame.eu/wp-content/uploads/2017/03/ECHRCJUEdialog.BRUSSELS. final-pdf. Accessed 8 April 2020. 
Europe but uniformity of EU law based on the principle of equality of Member States. Hence, the importance of the principle of mutual trust in EU law." ${ }^{4}$

\section{CROSS-CUTTING ISSUES}

In the European regional human rights system, we cannot exclude the possibility that certain issues will arise requiring both procedures to be referred to. According to Lemmens - inter alia - the following scenarios can be distinguished a) seeking advisory opinion with regard to a right or principle only enshrined in the ECHR, b) seeking advisory opinion with regard to a right secured both in EU law and in the ECHR. ${ }^{45}$

Under scenario a) there should not been any issues with regard to overlapping mechanisms, however the judicial and advisory functions of the ECtHR might collide with each other, meaning that it cannot be excluded that the same principle arises to be interpreted by the Court in a parallel way, in form of "regular" proceedings by committee or chamber and as per request for advisory opinion by the Grand Chamber. For the sake of coherence, in those cases it would be beneficial to suspend the contentious proceedings until the Grand Chamber rules on the interpretation in the form of an advisory opinion. In that hypothetical scenario it is also questionable whether the same judge can be involved in both proceedings.

If we take scenario b), the situation is a bit more complex, even without mentioning Opinion 2/13 delivered by the CJEU. This case could arise if the highest national court or tribunal has to answer a question which is safeguarded both by EU law, e.g. the Charter and the ECHR. Lacking a regulated institutional relationship, we can only rely on the Bosphorus-doctrine which was further nuanced in the case Avotinš v. Latvia, ${ }^{46}$ however in the current situation, "the "reconciliation exercise" carried out by the Strasbourg Court in the Bosphorus case(s) will now have to be performed by the domestic court." ${ }^{47}$

So far in similar situations the national courts first referred the question to the CJEU for preliminary ruling and eventually afterwards the individual claimant took it - or attempted

44 Spielmann, D., Ibid.

45 Lemmens, K., Protocol No. 16 to the ECHR: Managing Backlog trough Complex Judicial Dialogue? European Constitutional Law Review, Volume 15, Issue 4 December 2019, pp. 691-713.

46 Avotinš v. Latvia (Application no. 17502/07) ECLI:CE:ECHR:2016:0523JUD001750207 para. 116. "Accordingly, the Court must satisfy itself that, where the conditions for application of the Bosphorus presumption are met (see paragraphs 105-06 above), the mutual-recognition mechanisms do not leave any gap or particular situation which would render the protection of the human rights guaranteed by the Convention manifestly deficient. In doing so it takes into account, in a spirit of complementarity, the manner in which these mechanisms operate and in particular the aim of effectiveness which they pursue. Nevertheless, it must verify that the principle of mutual recognition is not applied automatically and mechanically (see, mutatis mutandis, $X v$. Latvia [GC], no. 27853/09, $\S \S 98$ and 107, ECHR 2013) to the detriment of fundamental rights - which, the CJEU has also stressed, must be observed in this context (see, for instance, its judgment in Alpha Bank Cyprus Ltd v. Dau Si Senh and Others, paragraph 48 above). In this spirit, where the courts of a State which is both a Contracting Party to the Convention and a member State of the European Union are called upon to apply a mutual-recognition mechanism established by EU law, they must give full effect to that mechanism where the protection of Convention rights cannot be considered manifestly deficient. However, if a serious and substantiated complaint is raised before them to the effect that the protection of a Convention right has been manifestly deficient and that this situation cannot be remedied by European Union law, they cannot refrain from examining that complaint on the sole ground that they are applying EU law." 
to take it - to the ECtHR. If we take the already cited Bosphorus case ${ }^{48}$ the ECtHR was already informed about the CJEU's stance ${ }^{49}$ by the time the case had made its way to Strasbourg, and could adopt its position accordingly. ${ }^{50}$

However, in the current scenario, if the national court refers the same question to both courts, i.e. to the CJEU to interpret and review EU law and to the ECtHR to provide guidance on the principle, this can be a source of divergence in the application of law, even if we can assume that the frequency of such scenarios is rather limited. In such cases the autonomy of EU law could come into question and the national courts could possibly be engaged in "forum shopping" between the Strasbourg and Luxembourg courts. I agree with Callewaert that in such cases it would be useful for the supreme courts of the EU Member States to be reminded in an appropriate way, when considering applying Protocol No. 16, of their duties under Art. 267 TFEU and of the supreme authority of the CJEU as regards the interpretation of EU law. "However, legally binding restrictions on the use of that Protocol would appear to be both disproportionate and unjustified." ${ }^{51}$ Furthermore, during the regular meetings of the two courts it would be useful to place on the agenda a proposal on some kind of coordinated cooperation approach arising from the application of both procedures. Thus, we could potentially get guidance also on a situation where the national court after referring to the CJEU as per Art. 267 TFEU later on decides to request an advisory opinion, at least until the lacking institutional link with EU is put in place.

When it comes to the level of protection, according to Article 53 ECHR, the Convention serves as a minimum standard setter, therefore the Contracting Parties may adopt higher level of protection. That is in line with Charter Article 52 (3) provisions offering the possibility for higher level protection. However, this conclusion was not endorsed in Opinion 2/13 delivered by CJEU. ${ }^{52}$

\section{CONCLUSIONS TO BE DRAWN FROM THE FIRST ECTHR ADVISORY OPINION}

Although from the first advisory opinion we cannot see any groundbreaking tendencies, issues or a redefined relationship, still it carries special importance as we can draw at least some conclusions on the functioning of this type of procedure. Let's look at the procedural aspects. The first advisory opinion asked a question concerning the recognition in domestic law of a legal parent-child relationship between a child born through a gestational surrogacy arrangement abroad and the intended mother. More specifically the two questions read as follows:

48 Bosphorus Hava Yollari Turizm ve Ticaret AS v Minister for Transport, Energy and Communications and others, C-84/95, ECLI:EU:C:1996:312.

49 Case of Bosphorus Hava Yollari Turizm ve Ticaret Anonim Sirketi v. Ireland, Application No.: 45036/98, ECLI:CE:ECHR:2005:0630JUD004503698.

50 Lemmens, K., Ibid. p. 704.

51 Callewaert, J., Protocol 16 and the Autonomy of EU law: who is threatening whom? https://europeanlawblog.eu/2014/10/03/protocol-16-and-the-autonomy-of-eu-law-who-is-threatening-whom/. Accessed 08 April 2020. 
"1. By refusing to enter in the register of births, marriages and deaths the details of the birth certificate of a child born abroad as the result of a gestational surrogacy arrangement, in so far as the certificate designates the ,intended mother' as the ,legal mother', while accepting registration in so far as the certificate designates the ,intended father', who is the child's biological father, is a State Party overstepping its margin of appreciation under Article 8 of the European Convention for the Protection of Human Rights and Fundamental Freedoms? In this connection should a distinction be drawn according to whether or not the child was conceived using the eggs of the ,intended mother'?

2. In the event of an answer in the affirmative to either of the two questions above, would the possibility for the intended mother to adopt the child of her spouse, the biological father, this being a means of establishing the legal mother-child relationship, ensure compliance with the requirements of Article 8 of the Convention?" 53

Both questions were answered affirmative. From the point of view of dialogue or discourse between courts it is important to note that French Court of Cassation referred the request for the advisory opinion after French Civil Judgments Review Court granted a request for re-examination of the appeal on points of law. ${ }^{54}$ Interestingly, the ECtHR already dealt with the case in its judgment in Mennesson v. France examining the compatibility of the case with Article 8. So, besides the dialogue between a national and an international court, another aspect which emerges from the first case is the question of the interference between two procedures established before the Court and their coherence.

The advisory opinion contains numerous references to the ECHR caselaw, as in the "regular" procedures. The Court will take into account its caselaw as a whole, regardless of type of procedure. This is in line with the statement that interpretation has to be consistent with the general spirit of the Convention, as stated in the case Soering v. United Kingdom. ${ }^{55}$

The five-judge panel of the Grand Chamber considered the request admissible. Although the court enjoys margin of appreciation to accept the request, the refusal should be reasoned. ${ }^{56}$ If the panel decides to accept the request for advisory opinion, then the case is referred to the Grand Chamber to decide. ${ }^{57}$ For the sake of comparison, in "regular" procedures the Grand Chamber engagement is only exceptional and can be considered as a sort of appeal. ${ }^{58}$

If the request for advisory opinion is accepted, a complex procedure will start. The time spent on that opinion will come to detriment of other judicial proceedings but also administrative issues of the court. Mainly because of the fact that the Grand Chamber engagement will require the Court's President and Vice-Presidents, the Section Presidents and the national judge, together with other judges selected by drawing of lots to consider their work in advisory opinion proceedings as priority ${ }^{59}$ putting on hold their other duties.

Advisory opinion, Ibid. para. 9.

Advisory opinion, Ibid. para. 16.

Soering v United Kingdom, Application no. 14038/88 ECLI:CE:ECHR:1989:0707JUD001403888 Paragraph 87.

Protocol No. 16, Article 2(1).

Protocol No. 16, Ibid.

This conclusion stems from Article 43. of the Convention.

See Rules of the Court, Article 93(2) https://www.echr.coe.int/Documents/Rules-Court-ENG.pdf. Accessed 8 April 2020 
One can just nurse hope that this complex and time-consuming process of delivering advisory opinion will be proportional to the usefulness of the given guidance.

The admissibility decision of the first advisory opinion is a positive message for the upcoming applicants too. The second request for advisory opinion came quite soon, in August 2019, this time the Constitutional Court of Armenia has asked the ECtHR to provide an advisory opinion on the Article of the country's Criminal Code which penalizes the overthrowing of the Constitutional order, a provision which is at issue in two cases currently pending in Armenia. ${ }^{60}$

I believe the relatively high number of third parties has at least two reasons. The first is the novelty of the procedure, and the second is the "hot topic". Article 8 deals with different aspects of personal and private life from several angles where no consensus between $47 \mathrm{CoE}$ members exists. This was the situation in the case subject to the first advisory opinion where the question related to certain case of overstepping margin of appreciation. As already mentioned, Protocol No. 16 foresees the possibility of third parties to take part in proceedings. Although in the concrete case, the CoE Human Rights Commissioner did not intervene as third party, which to me was a bit disappointing bearing in mind the proactive role taken by the current Commisisoner Mijatović since she took her office. Regardless, the number of third parties was relatively high e.g. the United Kingdom, the Czech Republic, the AIRE Centre and the French Ombudsman. ${ }^{61}$

The Court explicitly laid down that its task is not to reply to all the grounds and arguments submitted to it. Furthermore, under Protocol No. 16, the Court's role is not to rule in adversarial proceedings on contentious applications by means of a binding judgment but rather, within as short a time frame as possible, to provide the requesting court with guidance enabling it to ensure respect for Convention rights when determining the case before it. ${ }^{62}$

Agreeing with Antoine Buyse the advisory opinion certainly does not solve all issues related to gestational surrogacy. However, it represents an attempt to provide useful and relatively quick decision-making tool, delivered by an international court in its constitutional cloak to the requesting national court that find it useful to ask for it. ${ }^{63}$

\section{INSTEAD OF A CONCLUSION: SOME CONTEXTUALIZATION}

The paper attempted to outline two things. First, that the two non-adversarial proceedings i.e. advisory opinion and preliminary ruling procedure, despite the prima facie assumption cannot be regarded the same. Even ECHR judges -at least two of them- Siofra O'Leary and Tim Eicke share this view. ${ }^{64}$

\footnotetext{
60 Press release issued by the Registrar of the Court Accessed 08 April 2020.

61 Advisory opinion, Ibid. para 6.

62 Advisory opinion, Ibid. para 34.

63 Buyse, A., Analysis: The Strasbourg Court's First Advisory Opinion under Protocol 16. http://echrblog.blogspot.com/2019/05/the-european-courts-first-advisory.html. Accessed 20 February 2020.

64 O'Leary, S.; Eicke, T., Some Reflections on Protocol No.16. https://www.echr.coe.int/Documents/ Speech-20190125-O-LearyEicke-JY-ENG.pdf. Accessed 20 February 2020.
} 
Second point to make is about the foreseeably limited role and contribution of advisory opinions in the regional human rights protection system under the auspices of the ECtHR. The advisory opinion procedure simply has too many "ifs".

To support this allegation with quantitative data, in 2019 in "regular" that is to say judicial procedure the ECtHR allocated 44500 applications to different judicial formations, ${ }^{65}$ while the Grand Chamber delivered only one advisory opinion and its panel of 5 judges declared admissible another one. These statistics undermine also the actual caseload reduction desire, at least in short-term. Nevertheless, it should be considered that the advisory opinion is rather new procedure type not ratified by all state's parties, that can impact the frequency of its utilization.

Beside quantitative matters we should not forget either about qualitative limiting factors, such as the question off the willingness (or perhaps reluctance?) of national courts and the multi-conditional application. The application of the advisory opinion as a non-binding instrument will largely depend on a cooperative stance taken (or not) by the national courts. The general assumption, according to which the relationship between the ECtHR and the national courts is a cooperative one is quite superficial; one should just take a closer look at the number of Protocol No. 16 ratifications, furthermore the differing legal traditions and practices within the $47 \mathrm{CoE}$ states - are not reflected in this simplified statement. Therefore, the willingness for dialogue is also differing, in cases where the national courts agree with the concept of partnership and if they are willing to ask the Court for guidance ${ }^{66}$ only in those cases the assumption might be correct.

We cannot disregard the possibility that the advisory opinion will be applied merely for strategic and political reasons, "thereby spoiling the very idea of a dialogue between co-equal partners." ${ }^{67}$ However, it is relevant to elaborate on the broader context of judicial dialogue for both procedures. In my view, judicial dialogue, is relevant angle as we look the potential relationship between the two non-contentious procedures.

Although, according to Christina Eckes, instead of a dialogue, it is more suitable to use the term 'discourse', referring more loosely to 'running to and from' rather than to the purposeful directed exchange that 'dialogue' seems to evoke. I share this view since in the European regional human rights system the interaction ranges from 'ignoring' or 'appearing to have considered' to 'taking into account' or 'making references' ${ }^{68}$ In this regional system, with the increasing number of highest courts, "the interaction has moved from a dialogue to 'a roundtable discussion' or -so to say- 'multilogue.." 69

Since the Markcx judgment of the ECtHR ${ }^{70}$-and Ruttili ${ }^{71}$ on CJEU side- we are aware of the fact that Strasbourg and the Luxembourg Court take note of each other's decisions. The

65 ECHR - Analysis of Statistics 2019. https://www.echr.coe.int/Documents/Stats-analysis-2019-ENG.pdf. Accessed 20 February 2020.

66 Gerards, J., Ibid. p. 646.

67 Gerards, J., Ibid. p. 651.

68 Eckes, Ch., The Court of Justice's Participation in the Judicial Discourse: Theory and Practice in (eds.)M. Cremona \& A. Thies, The European Court of Justice and External Relations - Constitutional Challenges, Hart Publishing, Oxford, 2014.

69 Eckes, Ch., Ibid.

70 Markcx v. Belgium, Application no. 6833/74 ECLI:CE:ECHR:1979:0613JUD000683374 para 58. 
discourse between the CJEU and the ECtHR has gone through different phases, but still in the absence of EU accession to the ECHR, at least for the foreseeable future, informal dialogue will continue to be the defining feature of the relation between the CJEU and the ECtHR ${ }^{72}$ - and in that regard, the quasi-precedent system applied by both courts remains a crucial element. The interaction between the CJEU and the ECtHR may actually exert positive effects for the protection of fundamental rights, creating a virtuous race to the top in the protection of fundamental rights in Europe. ${ }^{73}$

The European multilevel system of rights protection is composed of layers that complement each other, instead of layers that are neatly separated according to their origin (constitutional, EU or international). As stated by Polakiewicz, uniformity is neither required nor desirable in a Europe composed of nation states, each with its own distinctive traditions of fundamental rights protection. ${ }^{74}$

The question in this case is whether, as in the case of "regular" proceedings where the ECtHR took the pioneering role and served as source of inspiration for Luxembourg court, in case of the advisory opinion, the roles will be reversed, i.e. as the CJEU has bigger experience with a similar procedure, will the ECtHR count on that experience? Will the ECtHR take into consideration the decisions of the EU Court in procedural and substantive terms?

Speaking of the relationship between two courts, it is also important to stress that the two Courts continue after Opinion 2/13 to keep communication channels open and interact at bilateral meetings organized in Luxembourg and in Strasbourg. ${ }^{75}$ As outlined earlier it would be useful to address some kind of coordinated cooperation in cases of potential parallel application of the preliminary ruling and advisory opinion procedures.

Referring to Opinion 2/13, we should not forget that it also tackled the potential future relationship between the preliminary ruling procedure and advisory opinion stating that the position of preliminary ruling procedure could be undermined. ${ }^{76}$

72 Fabbrini F.; Larik J., The Past, Present and Future of the Relations between the European Court of Justice and the European Court of Human Rights in: Yearbook of European Law, Vol. 35, p. 30.

73 Fabbrini, F.; Larik, J., Ibid. p. 27.

74 Polakiewicz, J., Europe's multi-layered human rights protection system:challenges, opportunities and risks, Lecture at Waseda University Tokyo, 14 March 2016, https://www.coe.int/en/web/dlapil/speeches-of-the-director/-/asset-publisher/ja71RsfCQTP7/content/ europe-s-multi-layered-human-rights-protection-system-challenges-opportunities-and-risks?inheritRedirect=false\#-ftn1. Accessed 08 April 2020.

Spielmann, D., Ibid.

76 According to Opinion 2/13 paras 196-199. In the third place, it must be pointed out that Protocol No 16 permits the highest courts and tribunals of the Member States to request the ECtHR to give advisory opinions on questions of principle relating to the interpretation or application of the rights and freedoms guaranteed by the ECHR or the protocols thereto, even though EU law requires those same courts or tribunals to submit a request to that end to the Court of Justice for a preliminary ruling under Article 267 TFEU.

It is indeed the case that the agreement envisaged does not provide for the accession of the EU as such to Protocol No 16 and that the latter was signed on 2 October 2013, that is to say, after the agreement reached by the negotiators in relation to the draft accession instruments, namely on 5 April 2013; nevertheless, since the ECHR would form an integral part of EU law, the mechanism established by that protocol could - notably where the issue concerns rights guaranteed by the Charter corresponding to those secured by the ECHR - affect the autonomy and effectiveness of the preliminary ruling procedure provided for in Article 267 TFEU.

In particular, it cannot be ruled out that a request for an advisory opinion made pursuant to Protocol No 16 by a court or tribunal of a Member State that has acceded to that protocol could trigger the procedure for the prior involvement of the Court of Justice, thus creating a risk that the preliminary ruling procedure provided for in Article 267 TFEU might be circumvented, a procedure which, as has been noted in paragraph 176 of this Opinion, is the keystone of the judicial system established by the Treaties. 
Another relevant phenomenon is the living instrument concept of the ECtHR. The ECHR is a more than 60 years old document, and since the Tyrer judgment the ECtHR has had the possibility to adjust it to present-day conditions, avoiding thus that its rules become obsolete.

“The Court's evolutive approach may also extend to procedural matters and lead to institutional adaptation. If we look at examples, when confronted with problems of a systemic nature, the Court developed the practice of pilot-judgments. In 2003 it started to accept unilateral declarations. And what about the countless measures to cope with the case-load: don't they reflect the living character of the Convention? These procedural innovations illustrate that the capacity to adapt is crucial for the Court's effectiveness - and, indeed, survival." 77

Therefore, it cannot be excluded that in the near future, by applying the living instrument concept to procedural issues - if consensus exists - the relevance and strength of advisory opinion will be upgraded.

In the European legal space, the national, EU and regional international norms form a multi-layered system. In that complex system the advisory opinion represents another layer-not too harsh though- and thus-at least for the ratifying states hypothetically means the strengthening of legal protection.

However, the optional nature of the advisory opinion procedure warns about its possibly limited effects. On the contrary, the preliminary ruling is marked by unprecedented success.

The big question is whether relevant common acquis will evolve showing some patterns of European regional human rights system's non-contentious procedures subsystem.

\section{REFERENCES}

\section{BOOKS}

1. Blutman, L., Az Európai Unió joga a gyakorlatban, HVG ORAC Budapest, 2014.

2. Karoliny, E.; Komanovics, A.; Mohay, Á.; Pánovics, A.; Szalayné Sándor, E., Az Európai Unió joga, Dialóg Campus, Budapest-Pécs, 2015.

3. Mohay, Á., A nemzetközi jog érvényesülése az uniós jogban. PTE ÁJK Európa Központ/Publikon, Pécs, 2019.

4. Mohay, Á., Az előzetes döntéshozatali eljárás. In: Mohay, Á.; Szalayné Sándor, E. (eds), Az Európai Unió joga: C/2. témakör: Az Európai Unió joga. Dialóg Campus, Budapest-Pécs 2015.

5. Shaw, M. N., International Law, Sixth edition, Cambridge University Press 2008.

By failing to make any provision in respect of the relationship between the mechanism established by Protocol No 16 and the preliminary ruling procedure provided for in Article 267 TFEU, the agreement envisaged is liable adversely to affect the autonomy and effectiveness of the latter procedure. Opinion 2/13 of the Court ECLI:EU:C:2014:2454. 


\section{JOURNALS}

1. Eckes, Ch., The Court of Justice's Participation in the Judicial Discourse: Theory and Practice in (eds.) M. Cremona \& A. Thies, The European Court of Justice and External Relations - Constitutional Challenges, Hart Publishing, Oxford, 2014.

2. Fabbrini F.; Larik J., The Past, Present and Future of the Relations between the European Court of Justice and the European Court of Human Rights in: Yearbook of European Law, Vol. 35.

3. Gerards J., Advisory Opinions, preliminary rulings and the new protocol No.16 to the European Convention on Human Rights: A comparative and critical Appraisal, Maastricht Journal of European and Comparative law, 2014, Issue 4.

4. Helfer R. L., Redesigning the European Court of Human Rights: Embeddedness as a Deep Structural Principle of the European Human Rights Regime The European Journal of International Law 2008, Vol. 19 no. 1, p.125.

5. Lemmens, K., Protocol No. 16 to the ECHR: Managing Backlog trough Complex Judicial Dialogue? European Constitutional Law Review, Volume 15, Issue 4 December 2019.

\section{LIST OF REGULATIONS, ACTS AND COURT DECISIONS}

1. Advisory opinion concerning the recognition in domestic law of a legal parent-child relationship between a child born through a gestational surrogacy arrangement abroad and the intended mother, Request no. P16-2018-001Para.

2. Al-Skeini and Others v. the United Kingdom 55721/07 ECLI:CE:ECHR:2011:0707 JUD005572107.

3. Avotinšs v. Latvia (Application no. 17502/07) ECLI:CE:ECHR:2016:0523JUD 001750207.

4. Banković and Others v. Belgium and Others 52207/99 ECLI:CE:ECHR:2001:1212 DEC005220799.

5. Bosphorus Hava Yollari Turizm ve Ticaret Anonim Sirketi v. Ireland, Application No.: 45036/98, ECLI:CE:ECHR:2005:0630JUD004503698.

6. Bosphorus Hava Yollari Turizm ve Ticaret AS v Minister for Transport, Energy and Communications and others, C-84/95, ECLI:EU:C:1996:312.

7. Dorsch Consult Ingenieurgesellschaft mbH v Council of the European Union and Commission of the European Communities C-54/96 ECLI:EU:C:1997:413.

8. Dumitru-Tudor Dorobantu C128/18, ECLI:EU:C:2019:857.

9. Erich Stauder v City of Ulm C-29-69, ECLI:EU:C:1969:57.

10. Markcx v. Belgium, Application no. 6833/74 ECLI:CE:ECHR:1979:0613JUD 000683374.

11. Mennesson v. France, Application No.:65192/11, ECLI:CE:ECHR: 2014: 0626JUD 006519211.

12. Opinion 2/13 of the Court ECLI:EU:C:2014:2454.

13. Protocol No. 16 to the Convention on the Protection of Human Rights and Fundamental Freedoms. Council of Europe Treaty Series No. 214 (CETS No.214).

14. Roland Rutili v Ministre de l'intérieur Case 36-75. ECLI:EU:C:1975:137.

15. Rules of Procedure of the Court of Justice OJ L 265/1.

16. Rules of the Court, https://www.echr.coe.int/Documents/Rules-Court-ENG.pdf. Accessed 8 April 2020.

17. Soering v United Kingdom, Application no. 14038/88 ECLI:CE:ECHR:1989: 0707JUD001403888. 
18. Treaty on European Union OJ 2012 C 326/1.

19. Tyrer v. United Kingdom 5856/72 ECLI:CE:ECHR:1978:0425JUD000585672.

20. Vivien Prais v Council of the European Communities, Opinion of Mr Advocate General Warner 1976. C 130-75, ECLI:ECLI:EU:C:1976:124.

\section{WEBSITE REFERENCES}

1. Brighton Declaration https://www.echr.coe.int/Documents/2012-Brighton-FinalDeclaration-ENG. pdf. Accessed 8 April 2020.

2. Buyse, A., Analysis: The Strasbourg Court's First Advisory Opinion under Protocol 16 http://echrblog. blogspot.com/2019/05/the-european-courts-first-advisory.html. Accessed 8 April 2020.

3. Callewaert, J., Protocol 16 and the Autonomy of EU law: who is threatening whom? https://europeanlawblog.eu/2014/10/03/protocol-16-and-the-autonomy-of-eu-law-who-is-threatening-whom/. Accessed 8 April 2020.

4. Chart of signatures and ratifications of Treaty 214, Protocol No. 16 to the Convention for the Protection of Human Rights and Fundamental Freedoms Status as of 14/04/2020 https://www.coe. int/en/web/conventions/full-list/-/conventions/treaty/214/signatures? p-auth=oN1OZ7Um. Accessed 8 April 2020.

5. ECHR - Analysis of Statistics 2019 https://www.echr.coe.int/Documents/Stats-analysis-2019ENG.pdf. Accessed 8 April 2020.

6. Guidelines on the implementation of the advisory-opinion procedure introduced by Protocol No. 16 to the Convention (as approved by the Plenary Court on 18 September 2017) https://www.echr.coe. int/Documents/Guidelines-P16-ENG.pdf.

7. https://www.echr.coe.int/Documents/Convention-ENG.pdf. Accessed 8 April 2020.

8. Izmir Declaration: https://www.echr.coe.int/Documents/2011-Izmir-FinalDeclaration-ENG.pdf. Accessed 8 April 2020.

9. Mohay Á., Plot twist? Case C-128/18 Dorobantu: detention conditions and the applicability of the ECHR in the EU legal order http://eulawanalysis.blogspot.com/search?q=plot+twist. Accessed 08 April 2020.

10. O'Leary, S.; Eicke, T., Some Reflections on Protocol No.16. https://www.echr.coe.int/Documents/Speech-20190125-O-Leary-Eicke-JY-ENG.pdf. Accessed 8 April 2020.

11. Paulus, A., Opening of the Judicial Year Seminar Judgments and Separate Opinions: Complementarity and Tensions https://www.echr.coe.int/Documents/Speech-20190125-Paulus-JY-ENG.pdf. Accessed 8 April 2020.

12. Polakiewicz, J., Europe's multi-layered human rights protection system: challenges, opportunities and risks, Lecture at Waseda University Tokyo, 14 March 2016, https://www.coe.int/en/web/dlapil/ speeches-of-the-director/-/asset-publisher/ja71RsfCQTP7/content/europe-s-multi-layered-human-rights-protection-system-challenges-opportunities-and-risks?inheritRedirect=false\#-ftn1. Accessed 8 April 2020.

13. Recommendations to national courts and tribunals, in relation to the initiation of preliminary ruling proceedings 2016/C 439/01. Accessed 14 April 2020.

14. Report of the Group of Wise Persons to the Committee of Ministers https://search.coe.int/cm/ Pages/result-details.aspx?ObjectID=09000016805d7893. Accessed 13 April 2020. 
15. Spielmann, D., The Judicial Dialogue between the European Court of Justice and the European Court of Human Rights Or how to remain good neighbors after the Opinion 2/13. http://www.fp7-frame.eu/ wp-content/uploads/2017/03/ECHRCJUEdialog BRUSSELS.final-pdf. Accessed 8 April 2020.

16. Statistics: https://www.echr.coe.int/Documents/Stats-violation-2019-ENG.pdf. Accessed 13 April 2020. 


\section{SAVJETODAVNO MIŠLJENJE I PRETHODNI POSTUPAK - USPOREDNA I KONTEKSTUALNA NAPOMENA}

\section{Summary}

Predmet ovog članka je Protokol br. 16 uz Europsku konvenciju o zaštiti ljudskih prava i temeljnih sloboda koji je nedavno stupio na snagu. U radu su predstavljeni glavni zajednički i razlikovni elementi dvaju izvanparničnih postupaka pred nadnacionalnim sudovima. Postupak savjetodavnog mišljenja Europskog suda za ljudska prava (ESLJP) i prethodni postupak obilježili su uspjeh bez presedana pred Sudom Europske unije, barem prima facie, za slične vrste postupaka. U radu se također analiziraju međusektorska pitanja koja proizlaze iz primjene obaju postupaka u istom slučaju koji se javljaju pred nacionalnim sudom ili sudištem. Iako je svrha savjetodavnog mišljenja postizanje i održavanje učinkovitosti, imajući na umu da je ESLJP žrtva vlastita uspjeha, u radu se navode određene ozbiljne sumnje i pretpostavke o tome hoće li se u sadašnjem obliku i u doglednoj budućnosti postići ta svrha. Rad također bliže razmatra postupovne aspekte prvog savjetodavnog mišljenja koje je donio ESLJP s obzirom na njegovu važnost, navodeći zaključke o funkcioniranju ove vrste postupka. Na kraju, daje se komparativni prikaz odnosa Europske konvencije o zaštiti ljudskih prava i temeljnih sloboda i prava Europske unije kao dva glavna povjerenika europskog višeslojnog sustava pravne zaštite.

Ključne riječi: $\quad$ Protokol br. 16, savjetodavno mišljenje, prethodni postupak, odnos Europske konvencije o zaštiti ljudskih prava i prava Europske unije

\section{(c) (i) \$}

This work is licensed under a Creative Commons

Attribution-NonCommercial 4.0 International License.

\footnotetext{
* Marija Daka, doktorandica. Pravni fakultet Sveučilišta u Pečuhu, Doktorska škola. Adresa: 7622 Pécs, 48-as tér 1, Republika Mađarska. E-pošta: marijadaka@gmail.com. ORCID: https://orcid.org/0000-0001-7961-2429.
} 